\title{
An Analysis of the Perceived Difficulties Arising During the Process of Integrating Management Systems
}

\author{
Jesus Abad $^{1}(\mathbb{D})$, Henrry Ricardo Cabrera ${ }^{2}$ (D) Alberto Medina $^{3}(\mathbb{D}$ \\ ${ }^{1}$ Universitat Politècnica de Catalunya (Spain) \\ ${ }^{2}$ Universidad de Cienfuegos (Cuba) \\ ${ }^{3}$ Universidad de Matanzas (Cuba) \\ jesus.abad@upc.edu,bricardo@ucf.edu.cu,alberto.medina@umcr.cu
}

Received: May 2016

Accepted: July 2016

\section{Abstract:}

Purpose: This study empirically scrutinises the difficulties that result from the integration of management systems and analyses the role of strategic actions and organisational factors on the difficulties-integration relationship.

Design/methodology/approach: For the empirical application we use a unique dataset of Spanish certified firms (ISO 9001, ISO 14001 and OHSAS 18001) with integrated management system. We employ an analysis based on nonparametric tests to detect differences in the distribution of perceived difficulties across groups of firms grouped according to strategic choices and business size.

Findings: Results show that the most relevant difficulty faced by managers is the employees' resistance to chance. Also, results suggest that the effective integration of management systems is conditioned by the sequence of integration of the systems, the integration level achieved and the structure governing the new integrated system. We also report a negative relationship between perceived difficulties and firm size.

Practical implications: For business strategists, our results underline the relevance of designing governance structures that match the requirements of the integrated system and interlock 
organisational and technical aspects at the design stage of the new integrated system. Additionally, the findings suggest that managers should also develop communication actions that increase the participation and involvement of workers at all stages of the integration process.

Originality/value: Most research emphasises the benefits of integrated management systems. By analysing the difficulties that arise during the integration process, this study contributes to fill a gap in the literature on the problems associated with processes of organisational change, in our case the integration of management systems.

Keywords: integrated management systems, ISO 9001, ISO 14001, OHSAS 18001, perceived difficulties

\section{Introduction}

The implementation of management systems based on international standards is a widespread practice among organisations seeking to ensure the demands of a variety of stakeholders. Research on the successful implementation of management systems is extensive in the case of quality management (ISO 9001) (Lafuente, Bayo-Moriones \& García-Cestona, 2010; Georgiev \& Georgiev, 2015), environmental management (ISO 14001) (Gavronski, Paiva, Teixeira \& De Andrade, 2013; Ciravegna \& Da Fonseca, 2015), and occupational health and safety management (OHSAS 18001) (Granerud \& Rocha, 2011; Abad, Lafuente \& Vilajosana, 2013). During the last decade, the integration of management systems has become an increasingly important strategy adopted by organisations, as it represents an alternative to operating with multiple management systems in parallel that cover different technical functions (Abad, Dalmau \& Vilajosana, 2014).

Previous studies dealing with integrated management systems (IMS) have primarily focused on three key issues, namely structures and models of the new management system (Wilkinson \& Dale, 2001; Ferguson, García \& Bornay, 2002; Beckmerhagen, Berg, Karapetrovic \& Willborn, 2003; Karapetrovic, 2003; Mackau, 2003; Pho \& Tambo, 2014); methodologies, approaches and strategies for the integration process (Karapetrovic, 2002; Jørgensen, Remmen \& Mellado, 2006; Bernardo, Casadesus, Karapetrovic \& Heras, 2009; Asif, Fisscher \& De Bruijn, 2010; De Oliveira, 2013); and the benefits that follow the integration of different management systems (Douglas \& Glen, 2000; Khanna, Laroiya \& Sharma, 2010; Zeng, Xie, Tam \& Shen, 2011; Tarí, Molina-Azorín \& Heras, 2012; Abad et al., 2014; Bernardo, Simon, Tarí \& Molina-Azorin, 2015).

Nevertheless, IMSs also face different problems that can tamper the integration process and its outcomes (Bernardo, Casadesus, Karapetrovic \& Heras, 2012a). To avoid the unsuccessful integration 
of management systems, organisations should also turn their attention to the difficulties associated with the implementation and maintenance of the new IMS (López-Fresno, 2010). However, literature on IMSs has not addressed in depth the difficulties associated with the integration of management systems.

Early studies analysed IMSs from a theoretical perspective, and they mostly identified the difficulties linked to the integration process (Tranmer, 1996; Jonker \& Klaver, 1998; Wilkinson \& Dale, 1999; Karapetrovic \& Willborn, 1998). Recently, research has started to pay attention and document the difficulties that result from the implementation of IMSs (Heras, Bernardo \& Casadesús, 2007; Zeng, Shi \& Lou, 2007; Salomone, 2008; Zeng, Tam \& Tam, 2008; Simon, Karapetrovic \& Casadesus, 2012). Although the increased interest in understanding how these difficulties emerge and affect the resulting IMS (Bernardo et al., 2012a), there is still a dearth of empirical research on this critical aspect of IMS.

In line with these arguments, the main objective guiding this paper is to empirically scrutinise the difficulties that emerge in the management systems integration process and to analyse the circumstances that trigger these difficulties.

The remainder of the paper is structured as follows. Section two presents the theoretical framework. Section three describes the data and the methodology chosen. Empirical results are offered in section four, and final conclusions are displayed in section five.

\section{Literature Review}

Most studies on the difficulties of integrating management systems adopt the taxonomy proposed by Zeng et al. (2007), who differentiate between internal and external difficulties. According to these authors, external factors affecting the implementation of IMS relate to technical guidelines, the role of certification bodies, inadequate support by consultants, and institutional environmental issues. Internal difficulties are associated with the lack of human resources, organisational structure and the business' culture.

The evident differences between standards are among the most frequently external difficulties reported in the literature. The lack of an ISO standard establishing the requirements of an IMS forces businesses to adopt "ad hoc" designs to deal with the integration of their management systems, following own integration strategies (Lopez-Fresno, 2010; Abad et al., 2014). Although the relatively high level of alignment and compatibility between standards, persistent dissimilarities between them still create problems to firms when designing the new management system (Matias \& Coelho, 2002; Salomone, 2008; 
Santos, Mendes \& Barbosa, 2011; De Oliveira, 2013). Also, some studies consider that the most important difficulties are the lack of specialised external consultants (Zutsi \& Sohal, 2005; Heras et al., 2007) or even the inadequate support by certification agencies (Zeng et al., 2007; Salomone, 2008). These problems may discourage the adoption of IMS or lead to an ineffective implementation.

Regarding the internal difficulties, Ferguson et al. (2002) consider that the organisational inertia-path dependency of management systems to work separately-is one of the biggest obstacles to the integration of management systems. Zeng et al. (2008) stress that firms have traditionally separate staff groups handling different management systems, which easily results in organisational conflicts.

Additionally, loss of managerial control on working methods has been identified as a relevant factor constraining the integration of different systems (Zutshi \& Sohal, 2005). This difficulty, linked to workers’ resistance to change, affects not only the introduction of new working methods or routines, but also the employees' motivation to face the challenges of the new IMS (Tarí \& Molina-Azorín, 2010). Additionally, it has been argued that resistance to change is the result of the lack of an adequate organisational culture in the business. Zeng et al. (2007) highlight that existing differences between management scope and culture likely lead to the creation of different sub-cultures within the organisation. Wilkinson and Dale (1999) argue that integration can only be achieved when all disciplines operate in a homogeneous organisational culture setting. Jørgensen (2008) discusses different levels of integration and considers that a uniform organisational culture that caters to the demands of various stakeholders is needed to reach full integration.

Other internal difficulties identified in the literature relate to the lack of financial, human and knowledge-based resources (Asif, Bruijn, Fisscher, Searcy \& Steenhuis, 2009; Simon et al., 2012) and poor involvement of top managers (López-Fresno, 2010; Gianni \& Gotzamani, 2015).

Finally, previous studies show that all these internal difficulties are reliant on both certain strategic decisions made during the design of the new management system and endogenous characteristics of the firm (Jonker \& Klaver, 1998; Zutshi \& Sohal, 2005; Asif et al., 2009; Sampaio, Saraiva \& Domingues, 2012; Bernardo, Casadesus, Karapetrovic, \& Heras, 2012b).

The theoretical deductions coming from the literature review lead us to conclude that previous studies mostly support the notion that integration of management systems is exposed to numerous difficulties that can lead to an unsuccessful integration. Yet, previous empirical research attempts to evaluate the impact and the background of these difficulties are almost inexistent. The abovementioned arguments further justify the study of the determinants of these difficulties; looking for a comprehensive analysis that allows scholars to better understanding the integration management systems process. 


\section{Data and Method}

The dataset used in this study was obtained from a survey developed in collaboration with the Spanish Association for Standardisation and Certification (AENOR). This agency is the leader in the certification of management systems in Spain. Data collection relied on a structured questionnaire where managers heading the integration system or the safety manager were asked to answer essentially closed questions. The questionnaire was subject to a pre-test in order to correct potentially misleading or confusing questions. In this sense, the instrument was submitted to six expert auditors to verify the appropriateness of the content of the items. In addition, three experts in research methodology revised the questionnaire in order for them to evaluate the clarity of the wording and the measurement scales used.

The questionnaire was directed to 548 Spanish firms operating in manufacturing, construction and service sectors. The mailing and data collection process took place between January and May 2009, and the survey was designed to provide information about selected organisational and performance characteristics of Spanish companies that implanted three standards granted by AENOR: quality (ISO 9001), environmental (ISO 14001) and occupational health and safety (OHSAS 18001) management systems. A total number of 110 observations were obtained, equating to a response rate of $20.07 \%$. In the interest of following a rigorous methodology, we included in the final sample only those observations for which a complete dataset of the dependent and independent variables could be constructed. Given this, eight observations were excluded from the final sample because questionnaires were not completed correctly. Therefore, the final sample consists of 102 valid surveys, representing an effective response rate of $18.61 \%$.

The questionnaire consists of three sections. The first section allows at obtaining the business size and the scope of the IMS. An analysis of the size distribution of the sample reveals that $28.74 \%$ of firms have 50 or less employees (small firms), whereas $52.87 \%$ of businesses fall into the medium-sized category (between 51 and 250 employees). Large firms represent 18.39\% of the sample. Prior to reporting the results, it is worth nothing than 86 out of the 102 sampled organisations reported an IMS, and the distribution of their scope follows: $92 \%$ integrated all three management systems, $5 \%$ integrated quality with environment, and 3\% integrated quality with occupational health and safety.

The second section includes questions concerning strategic decisions taken by firms during the design of the IMS. Similar to previous studies on IMSs, managers were asked about the following four strategic aspects:

- Sequence of integration. Following Labodová (2004), we asked managers about the path followed to integrate the management systems, namely progressive (simultaneous implementation of 
various systems followed by integration) or simultaneous (the direct implementation of the IMS covering all the analyzed management systems). Also, we asked the sequence of integration of the management systems chosen by the organization.

- Level of integration. To test the level of integration we followed the taxonomic proposal of Abad et al. (2014) which requires the identification of two crucial variables used to categorize the integration level of the IMS: the final documentation of the IMS, and the integration degree of the process map. In the former case, documentation is expressed as the number of written procedures of the IMS. For the latter variable, a set of dummy variables were used to corroborate whether the business integrated up to eight processes that are common to the three analysed management systems (management review, internal audits, management of preventive and corrective actions, control of non conformities, performance measurement and monitoring, document and data control, establishment and planning of objectives, external audits of certification).

- Administration of the IMS. The third strategic aspect of the instrument relates to the final organisational structure of the IMS, measured by the unification/separation of departments and managerial staff.

- Methodological model applied during integration. Managers were asked to indicate the integration model followed by the organization: the cross reference charts provided by international standards, and the Total Quality Management principles (Karapetrovic, 2003; Labodová, 2004; Asif et al., 2009).

Finally, to test for the presence of difficulties during the integration process we asked managers of firms with an IMS along a five-point Likert scale $(1=$ None; $2=$ Low; $3=$ Medium; $4=$ High and $5=$ Very high) to value the individual importance of five difficulties identified in the previous literature as potential barriers to the effective implementation of the IMS. Given the ordinal nature of the analysed perceived difficulties, we use the Kruskal-Wallis test to corroborate whether the perceived difficulties associated with the adoption of the IMS are linked to strategic issues of the design and implementation of the IMS (sequence of integration, levels of integration, organisational structure of the IMS and methodology applied for integrating the management systems), and to structural aspects of the analysed businesses, in our case business size. Through this nonparametric test we can detect distribution differences in the perceived difficulties across the different groups according the aspects analysed in the study (Kruskal \& Wallis, 1952: page 591). 


\section{Empirical Findings and Discussion}

This section presents the empirical findings. The first set of results in sub-section 4.1 shows the descriptive analysis of the selected difficulties integrating management systems, while sub-section 4.2 analyses whether the intensity of the analysed difficulties are statistically related to strategic decisions adopted by firms at the moment of designing the IMS and structural aspects of the business.

\subsection{Descriptive Analysis}

Figure 1 presents the frequency distribution of the 5 difficulties analysed in this study. The results show that the sampled organisations experienced few difficulties during the integration process. Note that for almost all the difficulties high and very high evaluations represent less than $10 \%$ of responses. In line with results reported by previous studies, the only exception is related to the employees' resistance to change (Zutshi \& Sohal, 2005; Bernardo et al., 2012a; Simon et al., 2012).

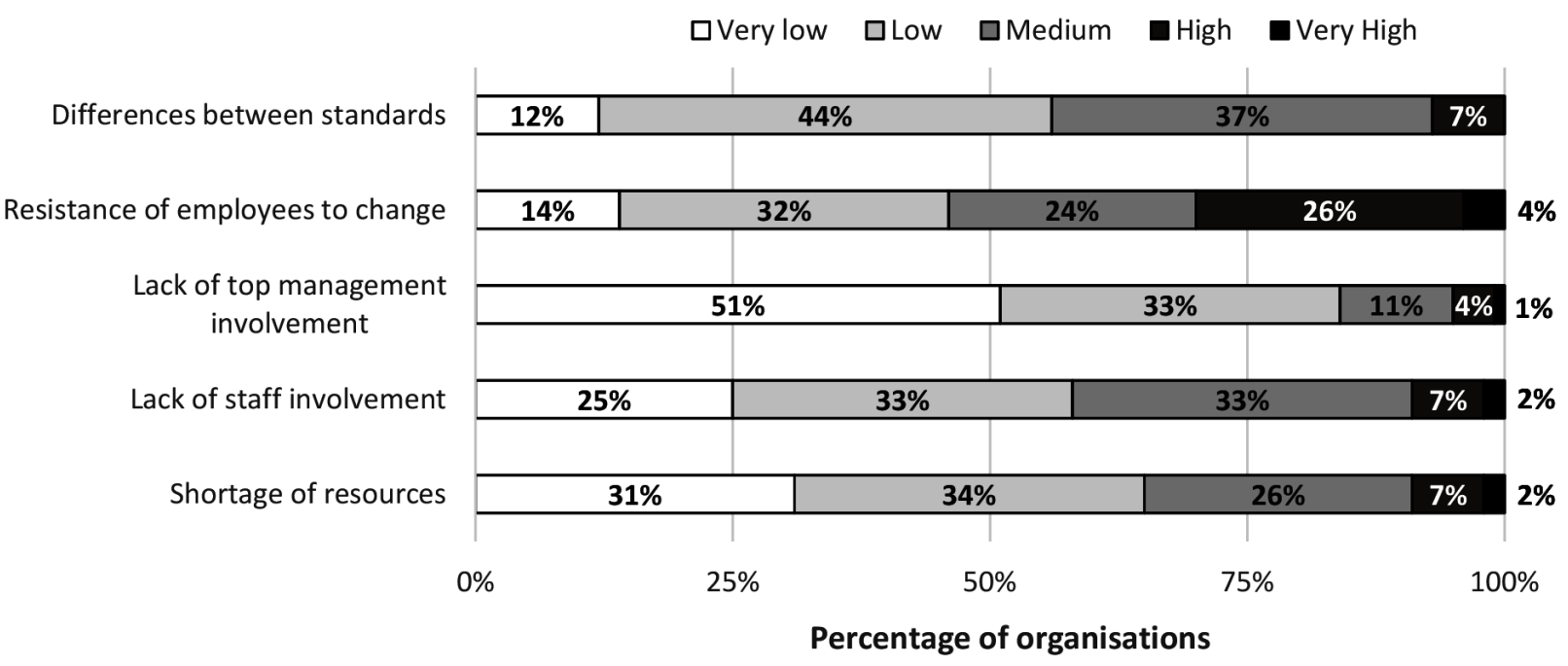

Figure 1. Degree of perceived difficulties during the integration of management systems

Prior studies support that poor leadership from top managers is one of the most critical aspects tampering the integration of management systems (Zutshi \& Sohal, 2005; Zeng et al., 2007; López-Fresno, 2010; De Oliveira, 2013; Almeida, Domingues \& Sampaio, 2014). Additionally, Gianni and Gotzamani (2015) found that weak commitment of top management teams is the main factor behind unsuccessful integration processes. However, and contrary to most previous research, the lack of 
leadership from top management is not identified as a key problem in most organisations involved in management system integration processes.

\subsection{Difficulties Integrating Management Systems Depending on Strategic Decisions}

When scrutinising the difficulties individually as a function of the integration sequence, results in Table 1 show that managers whose firms integrated the three management systems simultaneously (ISO 9001, ISO 14001 and OHSAS 18001) perceive higher difficulties, compared to managers of firms that integrated the management systems in a progressive way.

The results indicate that the most significant difficulty relates to the employees' resistance to change. This result is consistent with the notion that the simultaneous integration of management systems implies an abrupt change in existing work routines at all levels of the organisation. On contrary, the gradual integration of management systems allows the stepwise introduction of changes in work practices, thus facilitating the assimilation of these changes by employees. The findings in Table 1 suggest that the potential benefits of a gradual integration sway managers to adopt a progressive integration of management systems (see the number of observations for both sequences in Table 1). More concretely, $80.51 \%$ of the firms adopted an integration sequence in which ISO 9001 system was adopted first, followed by the ISO 14001 and the OHSAS 18001. This result is in line with the extensive literature on this topic (Karapetrovic \& Casadesús, 2009; Santos et al., 2011; Bernardo et al., 2012b).

\begin{tabular}{|c|c|c|c|c|c|}
\hline & \multicolumn{4}{|c|}{ Sequence of integration ${ }^{(a)}$} & \multirow{3}{*}{$\begin{array}{l}\text { Kruskal-Wallis } \\
\text { test }^{(\mathrm{b})}\end{array}$} \\
\hline & \multicolumn{2}{|c|}{ Progressive } & \multicolumn{2}{|c|}{ Simultaneous } & \\
\hline & Mean & Obs. & Mean & Obs. & \\
\hline Differences between standards & $\begin{array}{c}2.36 \\
(14.06 \%: 0.00 \%)\end{array}$ & 64 & $\begin{array}{c}2.54 \\
(0.00 \%: 0.00 \%)\end{array}$ & 13 & 0.464 \\
\hline $\begin{array}{c}\text { Resistance of employees to } \\
\text { change }\end{array}$ & $\begin{array}{c}2.56 \\
(17.19 \%: 3.13 \%)\end{array}$ & 64 & $\begin{array}{c}3.29 \\
(7.14 \%: 7.14 \%)\end{array}$ & 14 & $4.731 * *$ \\
\hline $\begin{array}{c}\text { Lack of top management } \\
\text { involvement }\end{array}$ & $\begin{array}{c}1.72 \\
(50.00 \%: 0.00 \%)\end{array}$ & 64 & $\begin{array}{c}1.57 \\
(50.00 \%: 0.00 \%)\end{array}$ & 14 & 0.117 \\
\hline Lack of staff involvement & $\begin{array}{c}2.23 \\
(26.56 \%: 1.56 \%)\end{array}$ & 64 & $\begin{array}{c}2.50 \\
(7.14 \%: 0.00 \%)\end{array}$ & 14 & 1.468 \\
\hline Shortage of resources & $\begin{array}{c}2.13 \\
(29.69 \%: 0.00 \%)\end{array}$ & 64 & $\begin{array}{c}2.36 \\
(21.43 \%: 7.14 \%)\end{array}$ & 14 & 0.306 \\
\hline
\end{tabular}

(a) For each difficulty analysed, values in brackets represent the proportion of firms with the lowest (1) and highest (5) valuation (i.e., figures should be read as "percentage of firms with the lowest valuation": "percentage of firms with the highest valuation").

(b) $*, * *, * * *$ indicates that the result is significant at the $10 \%, \% \%$ and $1 \%$, respectively.

Table 1. Kruskal-Wallis test: Difficulties according to the sequence of integration 
The second strategic topic analysed in this study refers to the level of integration achieved by the sampled businesses. To accurately assess the relationship between perceived difficulties and the level of integration we followed the taxonomic proposal of Abad et al. (2014). The authors provide empirical evidence of three levels of integration which are characterised by the IMS's documentation (lowest level of integration: documental harmonisation) and the final configuration of the IMS's process map (partial and full integration).

To accurately analyse the difficulties associated with high levels of integration of management systems, we excluded from the analysis four businesses that achieved the lowest level of integration (documental harmonisation). Overall, perceived difficulties are higher in businesses with a partial level of integration of management systems (see Table 2). This result is consistent with previous studies that confirm the relationship between the integration level achieved by the business and the difficulties arising during the integration process (Bernardo et al., 2012b).

Results in Table 2 also reveal significant differences in perceived difficulties (i.e., employees' resistance to change and low staff involvement) across integration levels. More concretely, managers whose businesses achieved a partial integration level underline the employees' resistance to change and low staff involvement as the main difficulties hampering the integration of management systems, compared to managers of businesses that achieved the full integration of management systems.

\begin{tabular}{|c|c|c|c|c|c|}
\hline & \multicolumn{4}{|c|}{ Level of integration (a) } & \multirow{3}{*}{$\begin{array}{l}\text { Kruskal-Wallis } \\
\text { test }^{\left({ }^{b}\right)}\end{array}$} \\
\hline & \multicolumn{2}{|c|}{ Full integration } & \multicolumn{2}{|c|}{ Partial integration } & \\
\hline & Mean & Obs. & Mean & Obs. & \\
\hline Differences between standards & $\begin{array}{c}2.38 \\
(14.29 \%: 0.00 \%)\end{array}$ & 42 & $\begin{array}{c}2.45 \\
(9.68 \%: 0.00 \%)\end{array}$ & 31 & 0.185 \\
\hline $\begin{array}{c}\text { Resistance of employees to } \\
\text { change }\end{array}$ & $\begin{array}{c}2.40 \\
(14.29 \%: 0.00 \%)\end{array}$ & 42 & $\begin{array}{c}3.13 \\
(12.50 \%: 9.38 \%)\end{array}$ & 32 & $7.619 * * *$ \\
\hline $\begin{array}{c}\text { Lack of top management } \\
\text { involvement }\end{array}$ & $\begin{array}{c}1.64 \\
(52.38 \%: 0.00 \%)\end{array}$ & 42 & $\begin{array}{c}1.78 \\
(43.75 \%: 0.00 \%)\end{array}$ & 32 & 0.295 \\
\hline Lack of staff involvement & $\begin{array}{c}2.12 \\
(26.19 \%: 0.00 \%)\end{array}$ & 42 & $\begin{array}{c}2.53 \\
(15.63 \%: 3.13 \%)\end{array}$ & 32 & $3.144 *$ \\
\hline Shortage of resources & $\begin{array}{c}2.17 \\
(28.57 \%: 2.38 \%)\end{array}$ & 42 & $\begin{array}{c}2.19 \\
(25.00 \%: 0.00 \%)\end{array}$ & 32 & 0.045 \\
\hline
\end{tabular}

${ }^{(a)}$ For each difficulty analysed, values in brackets represent the proportion of firms with the lowest (1) and highest (5) valuation (i.e., figures should be read as "percentage of firms with the lowest valuation": "percentage of firms with the highest valuation").

(b) $*, * *, * * *$ indicates that the result is significant at the $10 \%, \% \%$ and $1 \%$, respectively.

Table 2. Kruskal-Wallis test: Difficulties according to the integration level achieved 
The third set of aspects relates to the integration of the organisational structure of the IMS. The creation of a single department headed by a single manager is the most preferred organisational structure adopted by the sampled firms (48\%). Other structures include separate departments ran by either a single manager $(28 \%)$ or individual managers $(10 \%)$. The remaining $14 \%$ refer to other types of non-classifiable structures, such as a department with two managers or a management committee. Thus, and similar to Simon et al. (2012), our results in Table 3 show that businesses tend to unify managerial staff (76\% of businesses have a single manager); however, this does not hold for departments (only $48 \%$ of businesses have a single department).

\begin{tabular}{|c|c|c|c|c|c|c|}
\hline & \multicolumn{6}{|c|}{ Organisational structure ${ }^{(a)}$} \\
\hline & $\begin{array}{c}\text { One } \\
\text { Department } \\
\text { One Manager }\end{array}$ & Obs. & $\begin{array}{l}\text { Separated } \\
\text { Departments } \\
\text { One Manager }\end{array}$ & Obs. & $\begin{array}{c}\text { Separated } \\
\text { Departments } \\
\text { Different Managers }\end{array}$ & Obs. \\
\hline $\begin{array}{l}\text { Differences between } \\
\text { standards }\end{array}$ & $\begin{array}{c}2.32 \\
(15.79 \%: 0.00 \%)\end{array}$ & 38 & $\begin{array}{c}2.55 \\
(5.00 \%: 0.00 \%)\end{array}$ & 20 & $\begin{array}{c}2.00 \\
(28.57 \%: 0.00 \%)\end{array}$ & 7 \\
\hline $\begin{array}{l}\text { Resistance of employees } \\
\text { to change }\end{array}$ & $\begin{array}{c}2.53 \\
(23.68 \%: 2.63 \%)\end{array}$ & 38 & $\begin{array}{c}3.05 \\
(0.00 \%: 5.00 \%)\end{array}$ & 20 & $\begin{array}{c}2.75 \\
(25.00 \%: 12.50 \%)\end{array}$ & 8 \\
\hline $\begin{array}{l}\text { Lack of top } \\
\text { management } \\
\text { involvement }\end{array}$ & $\begin{array}{c}1.61 \\
(57.89 \%: 0.00 \%)\end{array}$ & 38 & $\begin{array}{c}1.80 \\
(40.00 \%: 0.00 \%)\end{array}$ & 20 & $\begin{array}{c}1.50 \\
(62.50 \%: 0.00 \%)\end{array}$ & 8 \\
\hline $\begin{array}{l}\text { Lack of staff } \\
\text { involvement }\end{array}$ & $\begin{array}{c}2.18 \\
(28.95 \%: 2.63 \%)\end{array}$ & 38 & $\begin{array}{c}2.55 \\
(15.00 \%: 0.00 \%)\end{array}$ & 20 & $\begin{array}{c}2.00 \\
(25.00 \%: 0.00 \%)\end{array}$ & 8 \\
\hline Shortage of resources & $\begin{array}{c}1.97 \\
(34.21 \%: 0.00 \%)\end{array}$ & 38 & $\begin{array}{c}2.55 \\
(15.00 \%: 0.00 \%)\end{array}$ & 20 & $\begin{array}{c}2.13 \\
(37.50 \%: 12.50 \%)\end{array}$ & 8 \\
\hline
\end{tabular}

(a) For each difficulty analysed, values in brackets represent the proportion of firms with the lowest (1) and highest (5) valuation (i.e., figures should be read as "percentage of firms with the lowest valuation": "percentage of firms with the highest valuation").

Table 3. Descriptive statistics for the difficulties according to the organisational structure of the IMS

From Table 3 we note that the creation of multiple departments ran by a single manager is the most troubling organisational structure during the integration of management systems. For this organisational structure values for all the analysed difficulties score the highest. On the contrary, the creation of separated departments headed by different managers is the organisational structure that shows the lowest level of perceived difficulties. As in Ferguson et al. (2002), this result indicates that "organizational inertia" (Rumelt, 1995), in this case the strong persistence of the systems to work separately, is one of the main obstacles to integration. Organisations often have separate competing staff groups that handle the different management systems. Therefore, integration may cause conflicts among these groups within the organisation (Zeng et al., 2007). Our results suggest that organisations that kept their original organisational structures faced lower integration barriers. 
A more in-depth analysis reveals that the most significant difficulties emerge when comparing a unified structure (one department governed by a single manager) and a structure where multiple departments manage the integrated systems. Results are statistically significant in the case of the difficulties related to the employees' resistance to change and the shortage of resources (see Table 4).

\begin{tabular}{|c|c|c|c|}
\hline & \multicolumn{3}{|c|}{ Organisational structures } \\
\hline & $\begin{array}{c}\text { One department / } \\
\text { One manager } \\
\text { vs. } \\
\text { Multiple departments / } \\
\text { One manager }\end{array}$ & $\begin{array}{c}\text { One department / } \\
\text { One manager } \\
\text { vs. } \\
\text { Multiple departments / } \\
\text { Multiple managers }\end{array}$ & $\begin{array}{l}\text { Multiple departments / } \\
\text { One manager } \\
\text { vs. } \\
\text { Multiple departments / } \\
\text { Multiple managers }\end{array}$ \\
\hline Differences between standards & 1.470 & 0.647 & 2.451 \\
\hline Resistance of employees to change & $2.779 *$ & 0.139 & 0.368 \\
\hline Lack of top management involvement & 1.234 & 0.061 & 0.891 \\
\hline Lack of staff involvement & 2.439 & 0.134 & 2.463 \\
\hline Shortage of resources & $4.452 * *$ & 0.001 & 1.476 \\
\hline
\end{tabular}

$*, * *, * * *$ indicates that the result is significant at the $10 \%, \% \%$ and $1 \%$, respectively.

Table 4. Kruskal-Wallis test: Difficulties according to the organisational structure of the IMS

Finally, we studied the relationship between perceived difficulties and the integration methodology adopted by the organisation. As we indicated in the literature review (section 2), an internationally accepted ISO standard establishing the requirements to integrate management systems is not available in the market. Thus, organisations dealing with management system integration have developed "ad hoc" designs based on their own integration strategies and goals (Ferguson et al., 2002; López-Fresno, 2010). In this scenario, managers mostly follow two widespread integration models: the cross reference charts provided by international standards and the Total Quality Management principles (see, e.g., Karapetrovic, 2003; Labodová, 2004; Asif et al., 2009). Although our results show that businesses that used the cross reference charts perceive more difficulties during the integration process, differences between the two types of methodologies are not statistically significant.

\subsection{Difficulties and Business Size}

Previous research has shown that firm size affects the decision to adopt ISO certifications (Adams, 1999; Lafuente et al., 2010). Thus, we argue that firm size might affect the implementation of an IMS. An exhaustive screening of the literature reveals that there are not many papers dealing with this issue, which signals a dearth of studies of the relationship between IMS, perceived difficulties and business size. 
Results in Table 5 show that, with the exception of the differences between standards, perceived difficulties are higher among managers running small businesses (less than 51 employees). Large firms with more than 250 employees show more problems to accurately harmonise the requirements of the three standards (ISO 9001, ISO 140901 and OHSAS 18001) during the integration process, which can be related to the increased complexity of operational processes in large businesses. These results are in sharp contrast to those reported by Salomone (2008) who finds that problems associated with the integration of management systems are greater in larger businesses.

\begin{tabular}{|c|c|c|c|c|c|c|}
\hline & \multicolumn{6}{|c|}{ Firm size ${ }^{(a)}$} \\
\hline & Small & Obs. & Medium & Obs. & Large & Obs. \\
\hline $\begin{array}{l}\text { Differences between } \\
\text { standards }\end{array}$ & $\begin{array}{c}2.35 \\
(15.00 \%: 0.00 \%)\end{array}$ & 20 & $\begin{array}{c}2.41 \\
(10.81 \%: 0.00 \%)\end{array}$ & 37 & $\begin{array}{c}2.50 \\
(8.33 \%: 0.00 \%)\end{array}$ & 12 \\
\hline $\begin{array}{c}\text { Resistance of } \\
\text { employees to change }\end{array}$ & $\begin{array}{c}2.95 \\
(20.00 \%: 10.00 \%)\end{array}$ & 20 & $\begin{array}{c}2.54 \\
(16.22 \%: 0.00 \%)\end{array}$ & 37 & $\begin{array}{c}2.42 \\
(16.67 \%: 0.00 \%)\end{array}$ & 12 \\
\hline $\begin{array}{l}\text { Lack of top } \\
\text { management } \\
\text { involvement }\end{array}$ & $\begin{array}{c}1.90 \\
(50.00 \%: 0.00 \%)\end{array}$ & 20 & $\begin{array}{c}1.73 \\
(43.24 \%: 0.00 \%)\end{array}$ & 37 & $\begin{array}{c}1.25 \\
(75.00 \%: 0.00 \%)\end{array}$ & 12 \\
\hline $\begin{array}{l}\text { Lack of staff } \\
\text { involvement }\end{array}$ & $\begin{array}{c}2.65 \\
(20.00 \%: 5.00 \%)\end{array}$ & 20 & $\begin{array}{c}2.32 \\
(18.92 \%: 0.00 \%)\end{array}$ & 37 & $\begin{array}{c}1.58 \\
(50.00 \%: 0.00 \%)\end{array}$ & 12 \\
\hline Shortage of resources & $\begin{array}{c}2.10 \\
(35.00 \%: 0.00 \%)\end{array}$ & 20 & $\begin{array}{c}2.30 \\
(18.92 \%: 0.00 \%)\end{array}$ & 37 & $\begin{array}{c}1.67 \\
(50.00 \%: 0.00 \%)\end{array}$ & 12 \\
\hline
\end{tabular}

(a) For each difficulty analysed, values in brackets represent the proportion of firms with the lowest (1) and highest (5) valuation (i.e., figures should be read as "percentage of firms with the lowest valuation": "percentage of firms with the highest valuation").

Table 5. Descriptive statistics for the difficulties according to the firm size

Finally, Table 6 shows the results of the comparison of the analysed difficulties across the different size categories (small, medium and large). The findings reveal that significant heterogeneity across size categories is significantly evident in the difficulties related to the lack of involvement by managers and employees.

More concretely, by looking the results in Tables 5 and 6 we note that the lack of involvement by both the staff and top managers decreases with respect to firm size. Organisational complexity is positively associated with business size (Peterson, 2012); therefore, a complex process—-such as the implementation of an IMS - can entail important organisational challenges related to the coordination between various functional areas. Existing research suggests that the lack of involvement might be linked to inadequate information systems that limit the organisation's capacity to introduce and manage the changes resulting from the integration of management systems (Klein \& Sorra, 1996). Additionally, in their case study of six businesses, Ferguson et al. (2002) find that large firms were more aware of this type of barrier, and 
that these businesses devoted more efforts in deploying a change management process that coordinates the different functional areas involved in the integration process and mitigates potential conflicts. On contrary, managers of small firms reported no awareness about the potentially negative effect of poor change management processes on the integration of management systems.

\begin{tabular}{|c|c|c|c|}
\hline \multirow{2}{*}{} & \multicolumn{2}{|c|}{ Firms' size } & Medium vs. large \\
\cline { 2 - 4 } & Small vs. medium & Small vs. large & 0.151 \\
\hline Differences between standards & 0.078 & 0.293 & 0.191 \\
\hline $\begin{array}{c}\text { Resistance of employees to change } \\
\text { Lack of top management } \\
\text { involvement }\end{array}$ & 1.632 & 1.440 & $4.186^{* *}$ \\
\hline Lack of staff involvement & 0.014 & $2.750^{*}$ & $6.769 * * *$ \\
\hline Shortage of resources & 1.233 & $7.135^{* * *}$ & $4.547^{* *}$ \\
\hline
\end{tabular}

$*, * *, * * *$ indicates that the result is significant at the $10 \%, \% \%$ and $1 \%$, respectively.

Table 6. Kruskal-Wallis test: Perceived difficulties between firm size categories

\section{Concluding Remarks}

Although previous studies emphasise the need to effectively manage the difficulties that may arise during the integration of management systems, research efforts have mostly addressed this issue from a theoretical perspective. Thus, this paper aims to fill this gap in the literature by examining the relationship between various organisational factors and the difficulties associated with IMS process, while acknowledging differences both in the strategic decisions linked to the design of the new system and in business size.

Although managers of companies with integrated management systems experienced few difficulties on the road to integration, the most important difficulty faced by managers relate to the employees' resistance to change. Managers can overcome this difficulty, or at least mitigate it, by implementing communication plans during the integration process, seeking to explain to employees the incentives to integrate their management systems, the expected benefits, as well as their role in the integration process. The results also show that resistance to change is more evident when the different systems are simultaneously integrated or when they are partially integrated. Thus, we suggest that managers should turn their attention to this barrier, and adopt mechanisms that increase the participation and involvement of workers at all stages of the integration process, that is, from the design of the new IMS to its full implementation. 
Another contribution of this study relates to the recognition that an effective integration process is conditioned not only by the design of technical and procedural guidelines, but also by the governance structure adopted by the organisation. Results show increased difficulties in businesses where the organisational chart remained unchanged and the IMS is governed by a single manager. Therefore, our results suggest the creation of a unified section (or department) headed by a single manager that handles all aspects of the new IMS. This aspect is of critical relevance as it underlines the importance of interlocking organisational and technical aspects at the design stage of the new integrated management system.

Finally, we report a negative relationship between perceived difficulties and firm size. Managers of small firms perceive more difficulties, and the degree of perceived difficulties systematically decreases with respect to business size. This is especially significant in the case of the difficulties related to the lack of involvement of both the staff and top managers. Although this result is different to those reported by previous studies (Salomone, 2008), we know that survival and performance is affected by business size (Aldrich \& Auster, 1986). A possible explanation for the relatively greater difficulties for integrating management systems reported among small firms' managers could relate to the liability of smallness hypothesis (Brüderl \& Schussler, 1990): the probability of survival (and superior performance) increases with respect to business size. According to Chowdury and Lang (1996), the liability of smallness results not only from the lack of financial resources, but also from managerial weaknesses related to deficiencies in the abilities of executives that lead to both low levels of flexibility and unwillingness to delegate tasks. An additional observable consequence of the liability of smallness is the difficulty of small firms in attracting skilled and qualified workforce, compared to large organizations whose structures and employment contracts are perceived as more reliable (Kale \& Arditi, 1998).

We are aware of the limitations of this study which in turn represent future lines of research. First, some of our results are contrary to those reported by previous empirical studies that have analysed the difficulties of system integration. Therefore, the debate is open and there remains a need for future research examining the difficulties during the integration of managements systems in different industry sectors and in different geographic contexts. Second, future studies should simultaneously evaluate the potential impact of different organisational aspects-i.e., governance structure, firm size-on the perceived benefits and difficulties that result from the integration of management systems. This type of analysis would enrich our understanding of IMS and would provide managers and business strategists with useful information that might improve decision-making processes linked to the integration of management systems. 


\section{References}

Abad, J., Lafuente, E., \& Vilajosana, J. (2013). An assessment of the OHSAS 18001 certification process: Objective drivers and consequences on safety performance and labour productivity. Safety Science, 60, 47-56. http://dx.doi.org/10.1016/j.ssci.2013.06.011

Abad, J., Dalmau, I, \& Vilajosana, J. (2014). Taxonomic proposal for integration levels of management systems based on empirical evidence and derived corporate benefits. Journal of Cleaner Production, 78, 164-173. http://dx.doi.org/10.1016/j.jclepro.2014.04.084

Adams, M. (1999). Determinants of ISO accreditation in the New Zealand manufacturing sector. Omega, 27, 285-292. http://dx.doi.org/10.1016/S0305-0483(98)00046-2

Aldrich, H.E., \& Auster, E. (1986). Even dwarfs started small: Liabilities of size and age and their strategic implications. Research in organizational behavior, 8, 165-198.

Almedia, J., Domingues, P., \& Sampaio, P. (2014). Different perspectives on management systems integration. Total Quality Management and Business Excellence, 25(3-4), 338-351.

http://dx.doi.org/10.1080/14783363.2013.867098

Asif, M., Bruijn, E., Fisscher, O., Searcy, C., \& Steenhuis, H. (2009). Process embedded design of integrated management systems. International Journal of Quality \& Reliability Management, 26(3), 261-282. http://dx.doi.org/10.1108/02656710910936735

Asif, M., Fisscher, O.A.M., \& De Bruijn, E.J. (2010). An examination of strategies employed for the integration of management systems. The TQM Journal, 22(6), 648-669.

http://dx.doi.org/10.1108/17542731011085320

Beckmerhagen, I.A., Berg, H.P., Karapetrovic, S., \& Willborn, W.O. (2003). Integration of management systems: focus on safety in the nuclear industry. International Journal of Quality \& Reliability Management, 20(2), 209-223. http://dx.doi.org/10.1108/02656710310456626

Bernardo, M., Casadesus, M., Karapetrovic, S., \& Heras, I. (2009). How integrated are environmental, quality and other standardized management systems? An empirical study. Journal of Cleaner Production, 17(8), 742-750. http://dx.doi.org/10.1016/j.jclepro.2008.11.003

Bernardo, M., Casadesus, M., Karapetrovic, S., \& Heras, I. (2012a). Do integration difficulties influence management system integration levels? Journal of Cleaner Production, 21(1), 23-33.

http://dx.doi.org/10.1016/j.jclepro.2011.09.008 
Bernardo, M., Casadesus, M., Karapetrovic, S., \& Heras, I. (2012b). Integration of standardized management systems: does the implementation order matter? International Journal of Operations \& Production Management, 32(3), 291-307. http://dx.doi.org/10.1108/01443571211212583

Bernardo, M., Simon, A., Tarí, J.J., \& Molina-Azorin, J.F. (2015). Benefits of management systems integration: a literature review. Journal of Cleaner Production, 94, 260-267.

http://dx.doi.org/10.1016/j.jclepro.2015.01.075

Brüderl, J., \& Schussler, R. (1990). Organizational Mortality: The Liabilities of Newness and Adolescence. Administrative Science Quarterly, 35(3), 530-547. http://dx.doi.org/10.2307/2393316

Ciravegna, L.M., \& Da Fonseca, M. (2015). ISO 14001:2015: An Improved Tool for Sustainability. Journal of Industrial Engineering and Management, 8(1), 37-50.

Chowdury, S.D., \& Lang, J.R. (1996). The Decline of Small Firms: A Preliminary Investigation into the Concept of Complacency. Canadian Journal of Administrative Sciences, 13(4), 321-331.

http://dx.doi.org/10.1111/j.1936-4490.1996.tb00741.x

De Oliveira, O.J. (2013). Guidelines for the integration of certifiable management systems in industrial companies. Journal of Cleaner Production, 57, 124-133. http://dx.doi.org/10.1016/j.jclepro.2013.06.037

Douglas, A., \& Glen, D. (2000). Integrated management systems in small and medium enterprises. Total Quality Management, 11(4-6), S686-S690. http://dx.doi.org/10.1080/09544120050008075

Ferguson, M.C., García, M., \& Bornay, M.M. (2002). Modelos de implantación de los sistemas integrados de gestión de la calidad, el medio ambiente y la seguridad. Investigaciones Europeas de Dirección y Economía de la Empresa, 8(1), 97-118.

Gavronski, L., Paiva, E.L., Teixeira, R., \& De Andrade, M.C.F. (2013). ISO 14001 certified plants in Brasil - taxonomy and practices. Journal of Cleaner Production, 39, 32-41.

http://dx.doi.org/10.1016/j.jclepro.2012.08.025

Georgiev, S., \& Georgiev, E. (2015). Motivational Factors for the Adoption of ISO 9001 Standards in Eastern Europe: The Case of Bulgaria. Journal of Industrial Engineering and Management, 8(3), 1020-1050. http://dx.doi.org/10.3926/jiem.1355

Gianni, M., \& Gotzamani, K. (2015). Management systems integration: lessons from an abandonment case. Journal of Cleaner Production, 86, 265-276. http://dx.doi.org/10.1016/j.jclepro.2014.08.023

Granerud, L., \& Rocha, R.S. (2011). Organisational learning and continuous improvement of health and safety in certified manufacturers. Safety Science, 49(7), 1030-1039. http://dx.doi.org/10.1016/j.ssci.2011.01.009 
Heras, I., Bernardo, M., \& Casadesús, M. (2007). La integración de sistemas de gestión basados en estándares internacionales: resultados de un estudio empírico realizado en la CAPV. Revista de Dirección y Administración de Empresas, 14, 155-174.

Jonker, J., \& Klaver, J. (1998). A methodological perspective on integration. Quality World, 24(8), 22-23.

Jørgensen, T.H., Remmen, A., \& Mellado, M.D. (2006). Integrated management systems - three different levels of integration. Journal of Cleaner Production, 14(8), 713-722.

http://dx.doi.org/10.1016/j.jclepro.2005.04.005

Jørgensen, T.H. (2008). Towards more sustainable management systems: through life cycle management and integration. Journal of Cleaner Production, 16(10), 1071-1080. http://dx.doi.org/10.1016/j.jclepro.2007.06.006

Kale, S., \& Arditi, D. (1998). Business Failures: Liabilities of Newness, Adolescence, and Smallness. Journal of Construction Engineering and Management, 124(6), 458-464. http://dx.doi.org/10.1061/(ASCE)07339364(1998)124:6(458)

Karapetrovic, S. (2002). Strategies for the integration of management systems and standards. The TQM Magazine, 14(1), 61-67. http://dx.doi.org/10.1108/09544780210414254

Karapetrovic, S. (2003). Musings on integrated management systems. Measuring Business Excellence, 7(1), 4-13. http://dx.doi.org/10.1108/13683040310466681

Karapetrovic, S., \& Casadesús, M. (2009). Implementing environmental with other standardized management systems: scope, sequence, time and integration. Journal of Cleaner Production, 17(5), 533-540. http://dx.doi.org/10.1016/j.jclepro.2008.09.006

Karapetrovic, S., \& Willborn, W. (1998). Integration of quality and environmental management systems. The TQM Magazine, 10(3), 204-213. http://dx.doi.org/10.1108/09544789810214800

Khanna, H.K., Laroiya, S.C., \& Sharma, D.D. (2010). Integrated management systems in Indian manufacturing organizations: some key findings from an empirical study. The TQM Journal, 22(6), 670-686. http://dx.doi.org/10.1108/17542731011085339

Klein, K.J., \& Sorra, J.S. (1996). The challenge of innovation implementation. The Academy of Management Review, 21(4), 1055-1080.

Kruskal, W.H., \& Wallis, W.A. (1952). Use of Ranks in One-Criterion Variance Analysis. Journal of the American Statistical Association, 47(260), 583-621. http://dx.doi.org/10.1080/01621459.1952.10483441 
Labodová, A. (2004). Implementing integrated management systems using risk analysis based approach. Journal of Cleaner Production, 12(6), 571-580. http://dx.doi.org/10.1016/j.jclepro.2003.08.008

Lafuente, E., Bayo-Moriones, A., \& García-Cestona, M (2010). ISO-9000 Certification and Ownership Structure: Effects upon Firm Performance. British Journal of Management, 21(3), 649-665. http://dx.doi.org/10.1111/j.1467-8551.2009.00660.x

López-Fresno, P. (2010). Implementation of an integrated management system in an airline: a case study. The TQM Journal, 22(6), 629-647. http://dx.doi.org/10.1108/17542731011085311

Mackau, D. (2003). SME integrated management system: a proposed experiences model. The TQM Magazine, 15(1), 43-51. http://dx.doi.org/10.1108/09544780310454448

Matias, J., \& Coelho, D. (2002). The integration of the standards systems of quality management, environmental management and occupational health and safety management. International Journal of Production Research, 40(15), 3857-3866. http://dx.doi.org/10.1080/00207540210155828

Peterson, K. (2012). Accounting complexity, misreporting, and the consequences of misreporting. Review of Accounting Studies, 17(1), 72-95. http://dx.doi.org/10.1007/s11142-011-9164-5

Pho H.T., \& Tambo, T. (2014). Integrated Management Systems and Workflow-Based Electronic Document Management: An Empirical Study. Journal of Engineering and Management, 7(1), 194-217. http://dx.doi.org/10.3926/jiem.846

Rumelt, R.P. (1995). Inertia and transformation. In Montgomery, C.A. (Ed.). Resource-Based and Evolutionary Theories of the Firm: Towards a Synthesis (pp. 101-132). Boston: Kluwer Academic Publisher. http://dx.doi.org/10.1007/978-1-4615-2201-0_5

Salomone, R. (2008). Integrated management systems: experiences in Italian organizations. Journal of Cleaner Production, 16(16), 1786-1806. http://dx.doi.org/10.1016/j.jclepro.2007.12.003

Sampaio, P., Saraiva, P., \& Domingues, P. (2012). Management systems: integration or addition? International Journal of Quality \& Reliability Management, 29(4), 402-424.

http://dx.doi.org/10.1108/02656711211224857

Santos, G., Mendes, F., \& Barbosa, J. (2011). Certification and integration of management systems: the experience of Portuguese small and medium enterprises. Journal of Cleaner Production, 19(17-18), 1965-1974. http://dx.doi.org/10.1016/j.jclepro.2011.06.017

Simon, A., Karapetrovic, S., \& Casadesus, M. (2012). Evolution of Integrated Management Systems in Spanish firms. Journal of Cleaner Production, 23(1), 8-19. http://dx.doi.org/10.1016/j.jclepro.2011.10.025 
Tarí, J.J., \& Molina-Azorín, J.F. (2010). Integration of quality management and environmental management systems. The TQM Journal, 22(6), 687-701. http://dx.doi.org/10.1108/17542731011085348

Tarí, J.J., Molina-Azorín, J.F., \& Heras, I. (2012). Benefits of the ISO 9001 and ISO 14001 standards: A literature review. Journal of Industrial Engineering and Management, 5(2), 297-322.

http://dx.doi.org/10.3926/jiem.488

Tranmer, J. (1996). Overcoming the problems of integrated management systems. Quality World, 22(10), 714-718.

Wilkinson, G., \& Dale, B.G. (1999). Integrated management systems: an examination of the concept and theory. The TQM Magazine, 11(2), 95-104. http://dx.doi.org/10.1108/09544789910257280

Wilkinson, G., \& Dale, B.G. (2001). Integrated management systems: a model based on a total quality approach. Managing Service Quality: An International Journal, 11(5), 318-330.

http://dx.doi.org/10.1108/09604520110404040

Zeng, S.X., Shi, J.J., \& Lou, G.X. (2007). A synergetic model for implementing an integrated management system: an empirical study in China. Journal of Cleaner Production, 15(18), 1760-1767. http://dx.doi.org/10.1016/j.jclepro.2006.03.007

Zeng, S.X., Tam, V.W.Y, \& Tam, C.M. (2008). Towards occupational health and safety systems in the construction industry of China. Safety Science, 46(8), 1155-1168. http://dx.doi.org/10.1016/j.ssci.2007.08.005

Zeng, S.X., Xie, X.M., Tam, C.M., \& Shen, L.Y. (2011). An empirical examination of benefits from implementing integrated management systems (IMS). Total Quality Management \& Business Excellence, 22(2), 173-186. http://dx.doi.org/10.1080/14783363.2010.530797

Zutshi, A., \& Sohal, A. (2005). Integrated management system. The experiences of three Australian organisations. Journal of Manufacturing Technology Management, 16(2), 211-232.

http://dx.doi.org/10.1108/17410380510576840

Journal of Industrial Engineering and Management, 2016 (www.jiem.org)

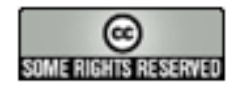

Article's contents are provided on an Attribution-Non Commercial 3.0 Creative commons license. Readers are allowed to copy, distribute and communicate article's contents, provided the author's and Journal of Industrial Engineering and Management's names are included. It must not be used for commercial purposes. To see the complete license contents, please visit http://creativecommons.org/licenses/by-nc/3.0/. 